\title{
Genetic variation of the Croatian beech stands (Fagus sylvatica L): spatial differentiation in connection with the environment
}

\author{
B Comps ${ }^{1 *}$, B Thiebaut 2 , I Sugar ${ }^{3}, 1$ Trinajstic ${ }^{4}$, M Plazibat 3 \\ 1 Université de Bordeaux I, Département de Biologie Végétale, \\ Avenue des Facultés, 33405 Talence Cedex; \\ 2 Centre Louis Emberger, CNRS, BP 5051, 34033 Montpellier Cedex; \\ Institut de Botanique, Université des Sciences et Techniques du Languedoc, \\ rue Auguste Broussonnet, Montpellier, France; \\ ${ }^{3}$ Botanicki Zavod, Fakulteta Sveucilista u Zagrebu, Marulicev trg 20/11, 41000 Zagreb; \\ 4 Sumarski Fakultet, Simunska Cesta, 4100 Zagreb, Yugoslavia
}

(Received 24 April 1990; accepted 15 October 1990)

\begin{abstract}
Summary - Thirty-five beech stands located in Croatia, (Yugoslavia) have been analysed using 6 polymorphic enzymatic loci. Three of them (PX-1, PX-2, GOT-1) seem to be more or less influenced by selection since their allelic frequencies are related to climatic conditions. The total gene diversity is higher for only 1 out of 6 loci in the continental region. Discriminant analyses on allelic frequencies show that the Mediterranean Seslerio-Fagetum which grows in rather dry conditions, is an association apart; and a significant difference exists between 2 groups of Mediterranean beechwoods located in the highlands and on the plain, respectively. A general tendency towards a heterozygotic deficit occurs with the same significance in both regions. Multilocus $F$-statistics reveal that the total genotypic differentiation and its 2 components (intra- and interpopulations) do not differ between the 2 regions.
\end{abstract}

genetic differentiation / beech population / Croatia / geographic variation

Résumé - La variation génétique des hêtraies croates (Fagus sylvatica $L$ ) : différenciation spatiale en relation avec l'environnement. Trente-cinq hêtraies localisées en Croatie (Yougoslavie) ont été étudiées à l'aide de 6 marqueurs enzymatiques polymorphes. Trois d'entre eux (PX-1, $P X-2, G O T-1)$ semblent plus ou moins soumis à la sélection, en particulier parce que leurs fréquences alléliques varient parallèlement aux conditions climatiques. La diversité allélique totale est plus élevée pour 1 locus sur 6 seulement, en région continentale. Deux analyses discriminantes sur les fréquences alléliques montrent:

- que le Seslerio-Fagetum méditerranéen qui caractérise des stations relativement sèches représente une association originale;

- une différence significative entre 2 groupes de hêtraies méditerranéennes en fonction de leur localisation soit en montagne, soit à basse altitude. Une tendance générale se manifeste vers un déficit en hétérozygotes de même importance dans les deux régions. Les F-statistiques montrent que la différenciation génotypique totale, aussi bien que ses 2 composantes (intra- et interpopulations) ne sont pas différentes d'une région à l'autre.

différenciation génétique / hêtraie / Croatie / variation géographique

* Correspondence and reprints 


\section{INTRODUCTION}

The genetic structure of beech stands depends on selection and the mating system, in addition to gene flow and genetic drift: these factors induce inter- and intrapopulation genetic differentiation over space and time (Kim, 1979; 1980; MüllerStarck, 1985, 1989; Cuguen, 1986; Gregorius et al, 1986; Cuguen et al, 1988).

Beech is a climax species in most of western Europe where it grows under various ecological conditions. Particularly close to the Mediterranean sea, neighbouring beechwoods may develop in very different climates, ie Mediterranean or continental climates, depending on whether they are located in the lowlands or in the highlands (Misic, 1957; Thiébaut, 1984). This environmental diversity favours the genetic differentiation of beechwoods by selection and genetic isolation due to phenological differences (Thiébaut et al, 1982; Felber and Thiébaut, 1982, 1984; N'Tsiba, 1984; Thiébaut, 1984; ; Barrière et al, 1985; Cuguen et al, 1985; Comps et al, 1987).

Beech is an anemophilous and mostly allogamic species characterized by a low self-fertilization rate (Nielsen and Schaffalitzky-de-Muckadell, 1954) which can nevertheless produce some heterozygotic deficit. In addition, gene flow may be generally limited within populations in the optimal beech range due to the high density of beechwoods: it is therefore likely that mating occurs between closely spaced individuals. According to Cuguen (1986) and Cuguen et al (1988), genetic structures should be approximately described by the "isolation by distance model" (Wright, 1943, 1946). This model induces a relatedness between individuals and therefore a genetic differentiation within and among populations (Cuguen, 1986). Since Wright's theoretical works, other methods and models have been proposed, which can best be applied to actual plant populations (Malécot, 1969; Gregorius, 1975a, b; Van Dijk, 1987).

Historical factors could also play an important role in the genetic structure of beechwoods. After the last glacial period, current beech stands spread out from a principal source located in the Balkans and from several secondary sources in southwestern Europe (Paquereau, 1965; Beug, 1967; Sercelj, 1970; Jalut et al, 1975; Triat-Laval, 1978; Pons, 1983). It appears that beech colonized its present areas at various periods: southern countries have been colonized since 5000 or $4000 \mathrm{BP}$ (approximately 40-50 generations) and northern plains since only 3000 or 2500 BP (25-30 generations) (Vernet, 1981). Thus there has been a higher number of generations in the south than in the north.

Genetic differentiation within and among beech stands seems to be higher in the south where ecological conditions are more heterogeneous, the stands are older and their sources more numerous (Comps et al, 1989). Our purpose was to examine the genetic differentiation of beechwoods in Croatia characterized both by the Mediterranean and continental climates. Preliminary results have shown that this genetic differentiation is higher in Croatia than in other countries of central Europe (Comps et al, 1989).

\section{MATERIAL AND METHODS}

\section{Sampling}

Sampling was carried out in 35 beech stands representing the various climatic conditions, the various soils and topographic locations where beech grows in Croatia (fig 1, table I). In each beech stand, plant material (buds and twigs) 


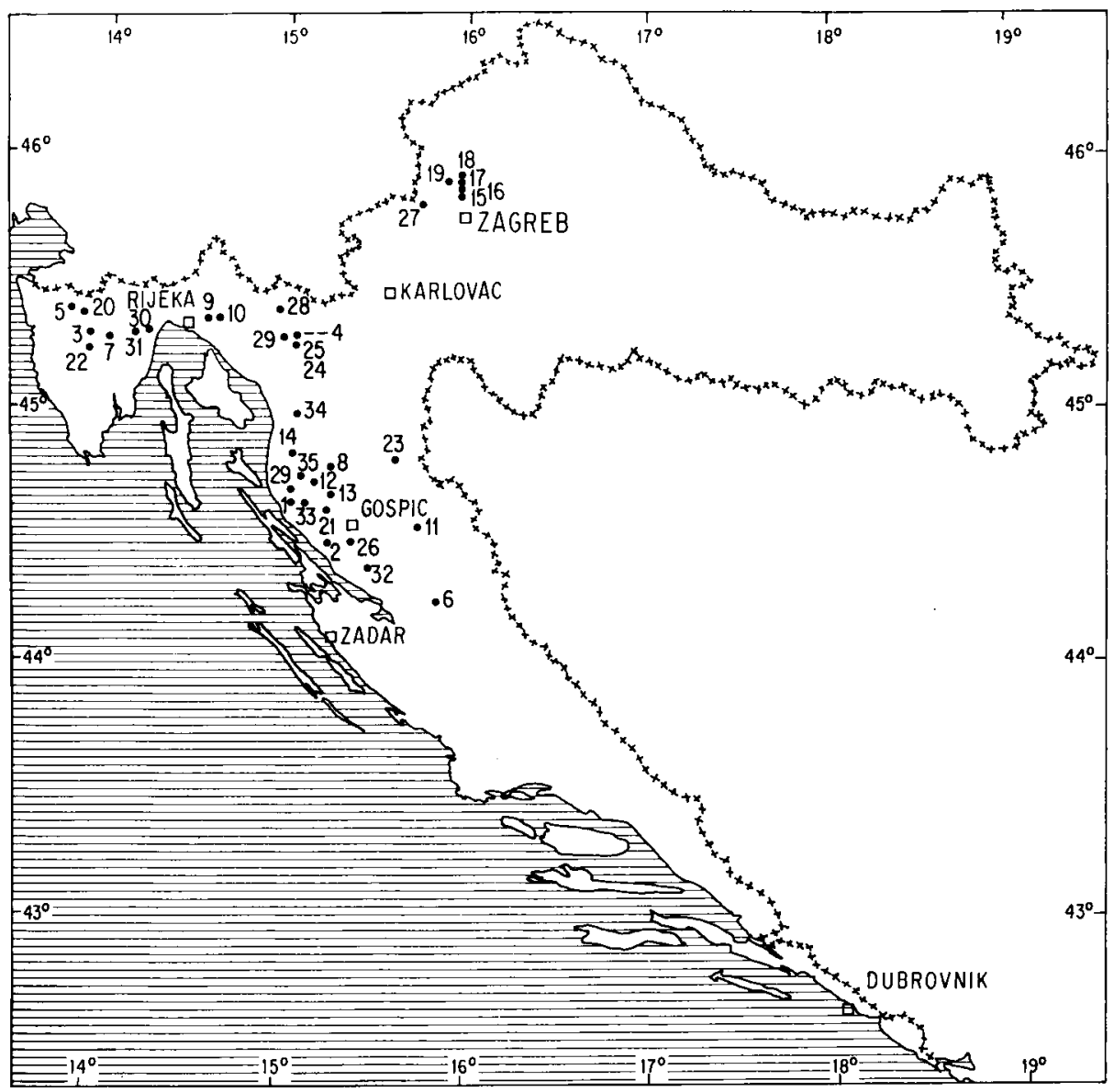

Fig 1. Location of the beechwoods studied in Croatia.

was sampled from about 50 trees chosen at random over a 3-4-ha area and in as homogeneous an environment as possible.

With regard to the climate, we compared 2 regions located on either side of the Dinaric Alps, in Mediterranean and continental climates, respectively. In the Mediterranean region, we also distinguished the forests located near the littoral at low altitude from the highland forests: the former are generally oak-beech mixed forests characterized by the dominance of oak and mostly located below $500 \mathrm{~m}$ in altitude (only one of them located at $800 \mathrm{~m}$ was included in this group due to the dryness of the station); the latter are beechwoods which are always located above $900 \mathrm{~m}$. The continental region was not subdivided: it includes all the forests located along the northern slope of the Dinaric Alps, on the plain and in the highlands of Croatia. With regard to soil factors, we could only define 3 classes of $\mathrm{pH}$ (acid, neutral and basic); we preferred to carry out a synthetic characterization of environment by analysing the plant associations to which the forests under study belong. 
Table I. Croatian beechwoods studied.

\begin{tabular}{|c|c|c|c|c|c|}
\hline & $\begin{array}{l}\text { Beechwood } \\
\text { locations }\end{array}$ & $\begin{array}{l}\text { Regional } \\
\text { climate }\end{array}$ & $\begin{array}{c}\text { Plant } \\
\text { associations }\end{array}$ & $\begin{array}{l}\text { Altitude } \\
(m)\end{array}$ & $\begin{array}{l}\text { Soil } \\
p H\end{array}$ \\
\hline 1 & Alancic & Ms & Fagetum-subalpinum & 1440 & Neutral \\
\hline 2 & Baske-Ostarije & Ms & Seslerio-Fagetum & 920 & Basic \\
\hline 3 & Bravari & $\mathrm{Mp}$ & Seslerio-Fagetum & 300 & Basic \\
\hline 4 & Brezovac & $\mathrm{C}$ & Fagetum-montanum & 850 & Neutral \\
\hline 5 & Cepici & Mp & Seslerio-Fagetum & 410 & Basic \\
\hline 6 & Crnopac & $\mathrm{c}$ & Seslerio-Fagetum & 780 & Basic \\
\hline 7 & Dausi & Mp & Seslerio-Fagetum & 445 & Basic \\
\hline 8 & Gacko Polje & $\mathrm{C}$ & Abieti-Fagetum & 600 & Neutral \\
\hline 9 & G Jelenje N & C & Abieti-Fagetum & 840 & Neutral \\
\hline 10 & G Jelenje S & Ms & Seslerio-Fagetum & 900 & Neutral \\
\hline 11 & Gorica & c & Seslerio-Fagetum & 802 & Basic \\
\hline 12 & Gromovaca & Ms & Fagetum-subalpinum & 1620 & Neutral \\
\hline 13 & Kalinovaca & $\mathrm{C}$ & Luzulo-Fagetum & 600 & Acid \\
\hline 14 & Krasno & $\mathrm{c}$ & Abieti-Fagetum & 750 & Acid \\
\hline 15 & Medvednica Sb & $\mathrm{C}$ & Luzulo-Fagetum & 400 & Neutral \\
\hline 16 & Medvednica SM1 & C & Fagetum-montanum & 500 & Acid \\
\hline 17 & Medvednica SM2 & c & Fagetum-montanum & 500 & Acid \\
\hline 18 & Medvednica $H$ & C & Aceri-Fraxinetum & 1020 & Neutral \\
\hline 19 & Medvednica N & $\mathrm{C}$ & Abieti-Fagetum & 500 & Neutral \\
\hline 20 & Oprtalj & $\mathrm{Mp}$ & Seslerio-Fagetum & 260 & Basic \\
\hline 21 & Pazariste & $\mathrm{C}$ & Abieti-Fagetum & 850 & Neutral \\
\hline 22 & Pazin & $\mathrm{Mp}$ & Anemone-Carpinetum & 300 & Basic \\
\hline 23 & Plitvice & c & Fagetum-montanum & 600 & Neutral \\
\hline 24 & Ponikve J & C & Fagetum-montanum & 350 & Basic \\
\hline 25 & Ponikve V & C & Fagetum-montanum & 350 & Basic \\
\hline 26 & Rizvanula & $\mathrm{C}$ & Luzulo-Fagetum & 600 & Acid \\
\hline 27 & Samoborsko & C & Luzulo-Fagetum & 450 & Neutral \\
\hline 28 & Skrad & $\mathrm{c}$ & Blechno-Fagetum & 550 & Acid \\
\hline 29 & Turinski Krc & Ms & Seslerio-Fagetum & 1130 & Basic \\
\hline 30 & Ucka E & Ms & Seslerio-Fagetum & 1000 & Basic \\
\hline 31 & Ucka W & Mp & Seslerio-Fagetum & 800 & Basic \\
\hline 32 & Velika Pak & Mp & Seslerio-Fagetum & 680 & Neutral \\
\hline 33 & Veliki Koz & Ms & Fagetum-subalpinum & 1400 & Neutral \\
\hline 34 & Vratnik & Ms & Seslerio-Fagetum & 900 & Neutral \\
\hline 35 & Vucjak & Ms & Fagetum-subalpinum & 1645 & Neutral \\
\hline
\end{tabular}

\section{Biochemical analysis}

Extraction from buds and cortical tissues of twigs, electrophoresis and staining were performed using the techniques described by Thiébaut et al (1982) and Merzeau et al (1989). Genetic variability was studied using 6 polymorphic loci: PX-1, PX-2 (peroxidases), GOT-1 (gluta- mate oxaloácetate transaminase), PGI-1 (phosphogluco-isomerase), $\mathrm{MDH}-1$ (malate dehydrogenase) and IDH-1 (isocitrate dehydrogenase). Three of these loci (PX-1, GOT-1 and MDH-1) possess 2 codominant alleles while the others have 3 codominant alleles (PX-2, $1 \mathrm{DH}-1$ and PGI-1) (Thiébaut et al, 1982; Merzeau et al, 1989). 


\section{Mathematical analyses}

\section{Allelic differentiation}

The total gene diversity $\left(H_{T}\right)$ was estimated using Nei's method $(1973,1977)\left({ }^{*}\right)$ :

$$
H_{T}=1-\Sigma p_{i}^{2}
$$

where $p_{i}$ is the mean frequency of the $i$ th allele, weighted by the sample size. We also estimated $H_{S}$ and $D_{S T}$ which are the weighted average gene diversities within and among populations, respectively, with $H_{T}=H_{S}+D_{S T}$.

Allelic frequencies of the different groups of beechwoods characterized according to climate, soil or plant associations were compared for each locus using an analysis of variance and the Mann-Whitney test. Gene diversities were compared using only the non parametric MannWhitney test because they did not fit a normal distribution. We then carried out a discriminant analysis including only the loci for which previous comparisons displayed significant differences. Only one allele was taken into account for each diallelic locus and only 2 for each triallelic locus.

\section{Genotypic differentiation}

Since the theoretical works of Wright (1965), genotypic structures have often been analysed using $F$-statistics. $F_{I T}$ is an estimation of the total genotypic differentiation, and allelic diversity is partitioned into intra- $\left(F_{I S}\right)$ and inter- $\left(F_{S T}\right)$ population components. Estimates of the $3 F$. statistics were made according to the method of Weir and Cockerham (1984). They were weighted by the stand sample size and its variance and by the number of stands studied. For each index, a variance was estimated using a jackknife procedure (Miller, 1974; Reynolds et al, 1983). This variance allowed us to determine whether each value was significantly different from 0 , and to test differences between 2 regions.

In populations which are not very polymorphic, negative $F_{I S}$ values are generally more frequent than within stands characterized by a high level of polymorphism: the corresponding heterozygote excess is connected with a statistical effect due to the low probability of encountering homozygotes of a rare allele in the sampling (Cuguen, 1986; Cuguen et al, 1988).

\section{RESULTS}

\section{Allelic differentiation}

At each locus, one allele generally appeared more frequently than the others in the beechwoods under study (table II). However for PX-1, the rarer allele (PX-1105) appeared more frequently in some Mediterranean forests located in the highlands (6 out of 7 stands) and only 2 out of 7 at low altitude.

\section{Allelic differentiation according to regions}

Gene diversity varied from one locus to another and according to the region. It was relatively high for $\mathrm{PX}-1, \mathrm{PX}-2, \mathrm{IDH}-1$ and $M D H-1$, whereas it was lower for GOT-1 and PGI-I (table III). It was higher for PX-1 in the Mediterranean region $(P<0.1)$ and for $\mathrm{MDH}-1$ in the continental region $(P<0.05)$ (table IV). In the Mediterranean region, the gene diversity was higher for 2 out 6 loci in the highlands: PX-2 $(P<0.001)$ and GOT-1 $(P<0.01)$ and was higher on the plain for $\mathrm{MDH}-1$ and $\mathrm{PGI}-1$ $\langle P<0.10)$.

Gene diversity was distributed in the same manner throughout, the greater part being within the forests $(86.9-99.1 \%$, table III) as observed in mostly allogamic species (Tigerstedt, 1973; Rudin et al, 1974; Lundkvist and Rudin, 1977; Hamrick et al,

(") As recommended by Nei (1973), we will use the word "gene diversity" instead of heterozygosity. 
Table II. Mean allelic frequencies according to regions and associations.

\begin{tabular}{|c|c|c|c|c|c|c|c|c|}
\hline \multicolumn{2}{|c|}{ Beechwood No } & \multirow{2}{*}{$\begin{array}{c}\text { All } \\
\text { beechwoods } \\
35\end{array}$} & \multicolumn{3}{|c|}{ Mediterranean region } & \multirow{2}{*}{$\begin{array}{c}\text { Continental } \\
\text { region } \\
19\end{array}$} & \multirow{2}{*}{$\begin{array}{c}\text { Seslerio } \\
\text { Fagetum } \\
13\end{array}$} & \multirow{2}{*}{$\begin{array}{l}\text { Other } \\
\text { associations } \\
22\end{array}$} \\
\hline & & & 7 & 9 & 16 & & & \\
\hline \multicolumn{9}{|c|}{ Loci, alleles } \\
\hline$P X-1$ & $\begin{array}{c}N \\
105 \\
100\end{array}$ & $\begin{array}{r}1897 \\
0.41 \\
0.59\end{array}$ & $\begin{array}{l}349 \\
0.40 \\
0.60\end{array}$ & $\begin{array}{l}556 \\
0.49 \\
0.51\end{array}$ & $\begin{array}{l}905 \\
0.46 \\
0.54\end{array}$ & $\begin{array}{l}992 \\
0.36 \\
0.64\end{array}$ & $\begin{array}{l}752 \\
0.45 \\
0.55\end{array}$ & $\begin{array}{r}1145 \\
0.37 \\
0.63\end{array}$ \\
\hline \multirow[t]{4}{*}{ PX-2 } & $N$ & 1908 & 350 & 559 & 909 & 999 & 756 & 1152 \\
\hline & 39 & 0.23 & 0.18 & 0.29 & 0.25 & 0.23 & 0.28 & 0.21 \\
\hline & 26 & 0.72 & 0.80 & 0.66 & 0.71 & 0.72 & 0.70 & 0.73 \\
\hline & 13 & 0.05 & 0.02 & 0.05 & 0.04 & 0.05 & 0.02 & 0.06 \\
\hline \multirow[t]{3}{*}{ GOT-1 } & $N$ & 1886 & 350 & 551 & 901 & 985 & 755 & 1131 \\
\hline & 105 & 0.06 & 0.04 & 0.08 & 0.07 & 0.05 & 0.07 & 0.05 \\
\hline & 100 & 0.94 & 0.96 & 0.92 & 0.93 & 0.95 & 0.93 & 0.95 \\
\hline \multirow{3}{*}{$\mathrm{MDH}-1$} & $N$ & 1784 & 346 & 547 & 893 & 891 & 744 & 1040 \\
\hline & 120 & 0.23 & 0.22 & 0.18 & 0.20 & 0.26 & 0.21 & 0.24 \\
\hline & 100 & 0.77 & 0.78 & 0.82 & 0.80 & 0.74 & 0.79 & 0.76 \\
\hline \multirow[t]{4}{*}{ IDH-1 } & $N$ & 1641 & 348 & 542 & 890 & 751 & 740 & 901 \\
\hline & 116 & 0.31 & 0.30 & 0.31 & 0.31 & 0.31 & 0.28 & 0.35 \\
\hline & 100 & 0.69 & 0.69 & 0.69 & 0.69 & 0.69 & 0.71 & 0.65 \\
\hline & 84 & 0.00 & 0.01 & 0.00 & 0.00 & 0.00 & 0.01 & 0.00 \\
\hline \multirow[t]{4}{*}{ PGI-1 } & $N$ & 1903 & 350 & 557 & 907 & 996 & 757 & 1146 \\
\hline & 113 & 0.00 & 0.01 & 0.00 & 0.00 & 0.00 & 0.00 & 0.01 \\
\hline & 100 & 0.98 & 0.93 & 0.98 & 0.96 & 0.98 & 0.98 & 0.97 \\
\hline & 87 & 0.02 & 0.06 & 0.02 & 0.04 & 0.02 & 0.02 & 0.02 \\
\hline
\end{tabular}

$N$, Tree number; ${ }^{1}$ lowlands; ${ }^{2}$ highlands; ${ }^{3}$ whole of the Mediterranean region.

1979; Loveless and Hamrick, 1984). However, the inter-population component varied somewhat according to region and locus.

Comparison of allelic frequencies between regions confirmed the contrast between the Mediterranean and the continental regions for PX-1 (table IV); we also found $0.05<P<0.10$ for MDH-1. In the Mediterranean region, the deviation between the lowlands and the highlands was confirmed for PX-2 and GOT-1.
A discriminant analysis was carried out including only PX-1, PX-2 and GOT-1 allelic frequencies for which the previous comparisons had shown significant deviations $(P<0.05$, table IV, fig 2$)$. It confirmed the difference' between the 2 groups of Mediterranean beechwoods (highland and lowland) for which discrimination was complete. Continental beechwoods constituted an intermediate group between the other two. GOT-1 and PX-2 loci were more responsible than $\mathrm{PX}-1$ for this discrimination between these climatic groups. 
Table III. Mean gene diversities according to regions and associations (Nei's procedure, 1973, 1974).

\begin{tabular}{|c|c|c|c|c|c|c|c|c|}
\hline \multirow{2}{*}{ Loci } & & \multirow{2}{*}{$\begin{array}{l}\text { Whole } \\
\text { area }\end{array}$} & \multicolumn{3}{|c|}{ Mediterranean region } & \multirow{2}{*}{$\begin{array}{c}\text { Continental } \\
\text { region }\end{array}$} & \multirow{2}{*}{$\begin{array}{l}\text { Seslerio- } \\
\text { Fagetum }\end{array}$} & \multirow{2}{*}{$\begin{array}{c}\text { Other } \\
\text { associations }\end{array}$} \\
\hline & & & 1 & 2 & 3 & & & \\
\hline$P X-1$ & $\begin{array}{l}H_{T} \\
H_{s}\end{array}$ & $\begin{array}{r}0.482 \\
94.6\end{array}$ & $\begin{array}{r}0.478 \\
94.2\end{array}$ & $\begin{array}{r}0.500 \\
96.1\end{array}$ & $\begin{array}{r}0.496 \\
94.5\end{array}$ & $\begin{array}{r}0.460 \\
96.7\end{array}$ & $\begin{array}{r}0.497 \\
95.6\end{array}$ & $\begin{array}{r}0.465 \\
95.5\end{array}$ \\
\hline$P X-2$ & $\begin{array}{l}H_{T} \\
H_{s}\end{array}$ & $\begin{array}{r}0.430 \\
96.3\end{array}$ & $\begin{array}{r}0.332 \\
98.3\end{array}$ & $\begin{array}{r}0.476 \\
97.6\end{array}$ & $\begin{array}{r}0.428 \\
96.1\end{array}$ & $\begin{array}{r}0.431 \\
96.8\end{array}$ & $\begin{array}{r}0.447 \\
95.9\end{array}$ & $\begin{array}{r}0.415 \\
97.7\end{array}$ \\
\hline GOT-1 & $\begin{array}{l}H_{T} \\
H_{s}\end{array}$ & $\begin{array}{r}0.116 \\
93.1\end{array}$ & $\begin{array}{r}0.084 \\
87.6\end{array}$ & $\begin{array}{r}0.144 \\
97.1\end{array}$ & $\begin{array}{r}0.122 \\
98.5\end{array}$ & $\begin{array}{r}0.108 \\
89.6\end{array}$ & $\begin{array}{r}0.129 \\
98.1\end{array}$ & $\begin{array}{r}0.104 \\
91.2\end{array}$ \\
\hline $\mathrm{MDH}-1$ & $\begin{array}{l}H_{T} \\
H_{s}\end{array}$ & $\begin{array}{r}0.348 \\
95.7\end{array}$ & $\begin{array}{r}0.347 \\
97.9\end{array}$ & $\begin{array}{r}0.298 \\
98.0\end{array}$ & $\begin{array}{r}0.317 \\
97.9\end{array}$ & $\begin{array}{r}0.376 \\
94.5\end{array}$ & $\begin{array}{r}0.329 \\
97.4\end{array}$ & $\begin{array}{r}0.362 \\
94.5\end{array}$ \\
\hline $\mid \mathrm{DH}-1$ & $\begin{array}{l}H_{T} \\
H_{s}\end{array}$ & $\begin{array}{r}0.434 \\
94.7\end{array}$ & $\begin{array}{r}0.433 \\
92.3\end{array}$ & $\begin{array}{r}0.435 \\
98.7\end{array}$ & $\begin{array}{r}0.434 \\
97.4\end{array}$ & $\begin{array}{r}0.434 \\
91.4\end{array}$ & $\begin{array}{r}0.412 \\
98.8\end{array}$ & $\begin{array}{r}0.450 \\
92.0\end{array}$ \\
\hline PGI-1 & $\begin{array}{l}H_{T} \\
H_{s}\end{array}$ & $\begin{array}{r}0.050 \\
94.0\end{array}$ & $\begin{array}{r}0.110 \\
92.0\end{array}$ & $\begin{array}{r}0.037 \\
94.2\end{array}$ & $\begin{array}{r}0.066 \\
91.9\end{array}$ & $\begin{array}{r}0.035 \\
95.9\end{array}$ & $\begin{array}{r}0.043 \\
99.1\end{array}$ & $\begin{array}{r}0.053 \\
86.9\end{array}$ \\
\hline $\begin{array}{l}\text { Mean } \\
\text { values }\end{array}$ & $\begin{array}{l}H_{T} \\
H_{s}\end{array}$ & $\begin{array}{r}0.310 \\
(0.047) \\
94.7\end{array}$ & $\begin{array}{r}0.297 \\
(0.067) \\
93.7\end{array}$ & $\begin{array}{r}0.315 \\
(0.078) \\
97.0\end{array}$ & $\begin{array}{r}0.311 \\
(0.013) \\
96.0\end{array}$ & $\begin{array}{r}0.307 \\
(0.027) \\
94.2\end{array}$ & $\begin{array}{r}0.310 \\
(0.014) \\
97.5\end{array}$ & $\begin{array}{r}0.308 \\
(0.014) \\
93.0\end{array}$ \\
\hline
\end{tabular}

$H_{T}$, Total gene diversity; $H_{S}$, weighted average gene diversity within populations (\%). ${ }^{1}$ Lowland; ${ }^{2}$ highland; ${ }^{3}$ whole of the Mediterranean region. Numbers in parentheses represent standard error.

\section{Allelic differentiation according to associations}

The originality of Croatian beechwood associations is mostly related to the existence of rather dry stands. This ecological character has induced the settlement of a special association, the Seslerio-Fagetum, whereas other beechwoods are more akin to those of Central Europe. This explains why we only compared this association with the others taken as a whole.

Gene diversity varied from one locus to another (table III). In Seslerio-Fagetum it was only found to be higher for PX-1
$(P<0.10)$ (table IV). The greatest part of gene diversity was always found to be within the populations, whatever the association group and the locus.

Comparisons of allelic frequencies between the 2 groups of associations showed significant differences for $\mathrm{PX}-1$, PX-2-39 and IDH-1 (table IV). Thus, there was a greater contrast between associations than between Mediterranean and continental regions.

A discriminant analysis including $P X-1$, $\mathrm{PX}-2$ and IDH-1 allelic frequencies (fig 3) confirmed the previous differences between the 2 groups of associations; but 
Table IV. Comparisons of allelic frequencies and diversities.

\begin{tabular}{|c|c|c|c|c|c|c|c|c|c|c|}
\hline & \multirow{2}{*}{$\begin{array}{l}\text { Loci } \\
\text { Alleles }\end{array}$} & \multirow{2}{*}{$\begin{array}{l}P X-1 \\
100\end{array}$} & \multicolumn{3}{|c|}{$P X-2$} & \multirow{2}{*}{$\begin{array}{l}\text { GOT-1 } \\
100\end{array}$} & \multirow{2}{*}{$\begin{array}{l}\text { MDH1- } \\
100\end{array}$} & \multicolumn{2}{|c|}{$I D H-1$} & \multirow{2}{*}{$\begin{array}{l}P G /-1 \\
100\end{array}$} \\
\hline & & & 26 & & 39 & & & 100 & 116 & \\
\hline \multicolumn{11}{|l|}{ Comparisons between : } \\
\hline & 1 & * & ns & & ns & ns & + & ns & ns & ns \\
\hline Mediterranean and & 2 & * & ns & & ns & ns & + & ns & ns & ns \\
\hline Continental regions & 3 & + & \multicolumn{3}{|c|}{ ns } & ns & $*$ & \multicolumn{2}{|c|}{$\mathrm{ns}$} & ns \\
\hline & 1 & ns & $* *$ & & * & * & ns & ns & ns & ns \\
\hline Mediterranean & 2 & $\mathrm{~ns}$ & $* *$ & & $*$ & $* *$ & ns & ns & ns & ns \\
\hline \multirow[t]{2}{*}{ highland and lowland } & 3 & ns & \multicolumn{3}{|c|}{$\star \star \star \star$} & $\star \star$ & + & \multicolumn{2}{|c|}{ ns } & + \\
\hline & 1 & + & ns & & * & ns & ns & * & * & ns \\
\hline \multirow{2}{*}{$\begin{array}{l}\text { Seslerio-Fagetum } \\
\text { and other associations }\end{array}$} & 2 & $*$ & ns & & * & ns & ns & * & * & ns \\
\hline & 3 & + & \multicolumn{3}{|c|}{ ns } & ns & ns & \multicolumn{2}{|c|}{ ns } & ns \\
\hline
\end{tabular}

1, ANOVA on allelic frequencies; 2 and 3, Mann-Whitney test, respectively on allelic frequencies and diversities; ns, non significant;,$+ 0.05<P<0.10 ;{ }^{*} 0.01<P<0.05 ;{ }^{* *}, 0.01<P<0.001{ }^{* * *}, P<0.001$.

their discrimination was not quite complete. The PX-2 locus was the most responsible for this discrimination.

\section{Genotypic differentiation}

For the whole of Croatia, all multilocus estimates of $F$-statistics were different from
0 , which implies the existence of genotypic differentiation both intra- and interpopulations (table V). $F_{I S}$ value was positive, which reveals a general tendency towards a heterozygote deficit.

The number of beechwoods and trees studied within each region were very alike, which allowed the comparison of $F$ statistics values. As for the whole of Croa-

Table V. Multilocus estimates of $F$-statistics according to regions and associations (Weir and Cockerman, 1984).

\begin{tabular}{|c|c|c|c|c|c|c|}
\hline \multirow{2}{*}{ Whole of Croatia [35] } & \multicolumn{2}{|c|}{$F_{I S} \pm 1$} & \multicolumn{2}{|c|}{$F_{S T} \pm 1$} & \multicolumn{2}{|c|}{$F_{I T} \pm I$} \\
\hline & 0.115 & 0.059 & 0.046 & 0.019 & 0.156 & 0.048 \\
\hline Continental region [19] & 0.090 & 0.052 & 0.036 & 0.028 & 0.123 & 0.034 \\
\hline Mediterranean region [16] & 0.068 & 0.065 & 0.055 & 0.048 & 0.120 & 0.068 \\
\hline Seslerio-Fagetum [13] & 0.085 & 0.081 & 0.037 & 0.019 & 0.119 & 0.091 \\
\hline Other associations [22] & 0.086 & 0.039 & 0.052 & 0.051 & 0.134 & 0.000 \\
\hline
\end{tabular}

I. Confidence interval $(P<0.05)$; the number of stands appears in parentheses. 


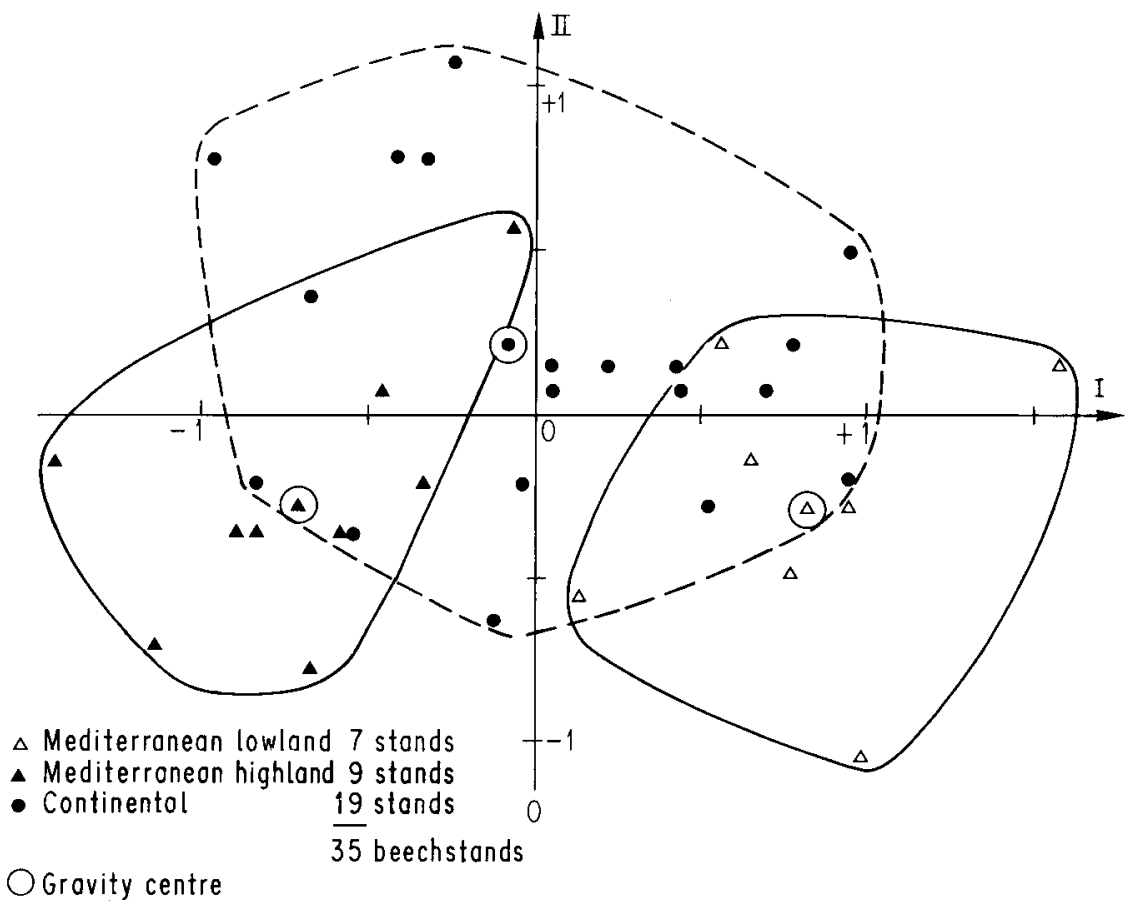

Fig 2. Discriminant analysis including $P X-1, P X-2$ and GOT-1 loci: comparison between climatic regions. Variance axis I: $69.97 \%$, axis II: $30.13 \%$. Variable discriminant values for GOT-1: -0.144 , PX2: $-0.100, \mathrm{PX}-1:-0.052$.

tia, all multilocus estimates differed from 0 , and $F_{I S}$ values were positive. Differences between the 2 regions were never significant. However, to similar $F_{I T}$ values tended to correspond lower $F_{I S}$ and higher $F_{S T}$ values in the Mediterranean region; but these differences were not significant. In the Mediterranean region, the comparison between lowland and highland beechwoods became impossible due to the low number of stands in each group.

Within each association group, all multilocus estimates of $F$-statistics were different from 0 . As for the regions, differences between any pair of homologous values taken from each group of associations respectively were never significant.

\section{DISCUSSION AND CONCLUSIONS}

The number of beechwoods studied was rather low as there is a variety of climate in Croatia. We could have sampled a greater number of stands on the mountain summits and within the continental region where beech is very frequent, but not along the littoral where beechwoods are rare. A lack of balance in the sampling which would have favoured the number of beechwoods studied belonging to the first group could have introduced a bias in our analysis. However, as the total number of trees analysed was great in both cases, the previous disadvantage was partially compensated. It would be interesting to 


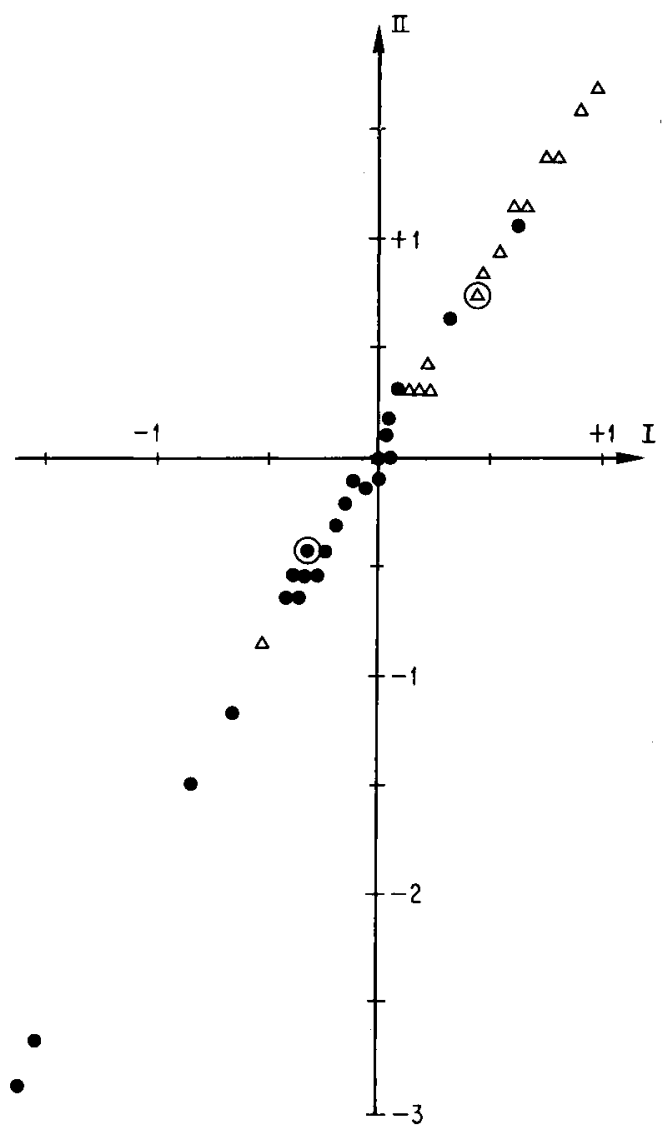

$\begin{array}{ll}\Delta \text { Seslerio-fogetum } & 13 \text { stands } \\ \text { - other plant ossociations } \frac{22}{35} \text { stands } & \text { beechstonds } \\ & \text { grovity centre }\end{array}$

Fig 3. Discriminant analysis including $P X-1, P X-$ 2 and IDH-1: comparison between the 2 groups of associations. Variable discriminant values for PX-1: - 0.151, PX-2: 0.025, IDH-1: 0.022. Coordinates are the same on the 2 axes (only 2 groups of stands).

sample over a wider area along the Dinaric chain as far as Macedonia, particularly in the lowlands.
In Croatia, 4 loci are regularly polymorphic (PX-1, PX-2, MDH-1 and IDH-1) and the other 2 less so (GOT-1, PGI-1) (table II). Allelic variations could be connected with climate for PX-1, PX-2, GOT-1 and with plant associations for PX-1, PX-2 and $\mathrm{IDH}-1$ (table IV, figs 2 and 3). There is a greater difference between the 2 groups of associations than between Mediterranean and continental regions. This may be due to the existence in the Mediterranean region of an association, Fagetum subalpinum (4 stands) very different from the Seslerio-Fagetum and more hygrophilous, which tends to reduce deviations between the 2 regions. This result confirms the originality of the Seslerio-Fagetum which characterizes the driest stands of the Croatian beechwoods.

On this scale, either PX-1 or PX-2 appear to be subject to genetic selection following environmental changes. This observation confirms some previous results (Thiébaut et al, 1982; Thiébaut, 1984; Barrière et al, 1985; Comps et al, 1987): in other southern countries, we found a positive correlation between $\mathrm{PX}-2$ allelic diversity and the extent of climatic variations connected with the altitudinal range of the stands. For $\mathrm{PX}-1$, a positive correlation was shown between extreme climatic conditions for beech and the highest values of PX-1-105 frequency. The dry conditions to which Seslerio-Fagetum is subject seem to be the most unfavourable to the growth of the beech in Croatia and also correspond to the highest frequencies of the same allele in this country.

On the other hand, in Southwestern Europe where GOT-1 polymorphism is high, the frequency of the GOT-1-105 allele is significantly higher under severe climate conditions at high altitude (Comps et al, 1987). In Croatia, in spite of the low polymorphism of this locus, its allelic frequency 
is also connected with altitudinal climatic changes (higher diversity in the highlands).

Taking into account all these observations, it should be noted that the 3 mentioned loci may be subject to selection. Koehn (1978) considered it is necessary to display the interrelations between phenotypic diversity, physiological reaction and variations of environmental factors in order to prove the adaptative signification of an enzymatic polymorphism. However, the connections between climate and allelic variations of PX-1, PX-2 and GOT-1 have been exhibited in different regions, each apart from the others. Even if the repetition of such a phenomenon does not constitute an indisputable proof of a selection effect, it is nevertheless a favourable argument (Clarke, 1975; Bergmann, 1978).

By using a greater number of loci, this study complements our previous results: in Croatia, allelic frequencies of $2 / 3$ newly used loci (MDH-1, PGI-1) do not vary substantially as a function of environmental factors, even if $\mathrm{MDH}-1$ gene diversity differs according to the region. IDH-I locus does not seem to be connected with regional climate; however, its polymorphism is significantly lower in Seslerio-Fagetum subject to dry conditions than in the other more mesophilous associations.

Multilocus F-statistics reveal a total genotypic differentiation which does not differ whatever the climate (table V). The intra- is higher than the inter-component, as observed by various authors (Sakai and Park, 1971; Mitton et al, 1977, 1981; Linhart et al, 1981; Knowles, 1984; Knowles and Grant, 1985; Shea, 1985; Cuguen, 1986). All $F_{I S}$ values are positive, which implies a general tendency towards a heterozygotic deficit. These observations confirm previous results obtained throughout Europe (Cuguen, 1986). As the selffertilization rate of beech is low (from 0 to $0.05)$; isolation by distance within each population (ie a Wahlund effect) can mostly explain the observed deficits.

The arguments put forward in the Introduction suggest that there has been more opportunity for the development of genetic differentiation among and within populations close to the Mediterranean sea. To what extent do our results confirm this hypothesis?

Only the allelic frequencies of $\mathrm{PX}-1$ locus differ significantly between the continental and the Mediterranean regions (table IV); in the latter the corresponding gene diversity is higher, but only at the 0.10 level. The discriminant analysis does not allow us to entirely separate one region from the other (fig 2). Allelic differentiation is not clearly higher within SeslerioFagetum which is chiefly a Mediterranean association than in the other mostly continental associations (table III). However, comparisons of allelic frequencies between the 2 groups of associations display a greater contrast than between regions (table IV).

Over the whole of Croatia, a genotypic differentiation within and among populations is clearly apparent. However, comparisons of the corresponding $F$-statistics values between the Mediterranean and continental regions do not display any significant deviations. Comparisons of $F$ statistic values between the 2 groups of associations lead to the same result. However, the lack of genotypic differences between 2 regions is probably increased for 2 reasons : 1) the methods employed may be limiting (jackknife); 2) due to a biological reality which is more complex and less perceptible at the genotypic than at the allelic level.

Finally, very few arguments confirm previous hypotheses, at least on the Croatian scale. Of course, on this scale, the time which as elapsed between the settlement 
of Mediterranean and that of continental beechwoods may be insufficient. To test the validity of our hypothesis, we are carrying out a study to compare the beech stands of Croatia, a part of Yugoslavia located close to the Mediterranean, with the Slovak beech stands in central Europe. Our hypothesis will be confirmed if the genetic differentiation is found to be higher in Croatia.

\section{ACKNOWLEDGMENTS}

This research was carried out with the financial support of the INRA contract 1233 A: "Amelioration, sylviculture et qualité du bois des feuillus précieux". The authors are grateful to RM Guilbaud, J Letouzey and S Vodichon for their technical assistance.

\section{REFERENCES}

Barrière G, Comps B, Cuguen J, N'Tsiba F, Thiebaut B (1985) The genetical ecological variability of beech (Fagus sylvatica $L$ ) in Europe - an alloenzymatic study: genetic isolations of beechwoods. In: Proc 1st Symp Improvement and Silviculture of Beech. IUFRO Project Group P1 10-00, Grosshansdorf 1984, 24-50

Bergmann $F(1978)$ The allelic distribution at an acid phosphatase locus in Norway spruce (Picea abies) along similar climatic gradients . Theor Appl Genet 32, 57-64

Beug HJ (1967) On the forest history of the Dalmatian coast. Rev Paléobot Palynol 2, 271 279

Clarke B (1975) The contribution of ecological genetics to evolutionary theory: detecting the direct effects of natural selection on particular polymorphic loci. Genetics 79, 101-113

Comps B, Barrière G, Merzeau D, Letouzey J (1987) La variabilité alloenzymatique des hêtraies dans les sous-domaines médio- et euatlantiques d'Europe. Can J For Res 17, 1043-1049
Comps B, Paule L, Sugar I, Thiebaut B, Trinajstic $Y$ (1989) Genetic variability in beechwoods (Fagus sylvatica L) over central Europe, allozymic variations in six enzyme systems: spatial differentiation among and within populations. In: Proc 3rd Symp $/ \mathrm{m}$ provement and Silviculture of Beech, 1988, IUFRO Project Group P1, Zvolen, Czechosiovakia, $10-00$

Cuguen J (1986) Différenciation génétique interet intrapopulations d'un arbre forestier anémophile : le cas du hêtre (Fagus sylvatica L). Thèse de Doctorat, Université des Sciences et Techniques du Languedoc, Montpellier, France

Cuguen J, Thiebaut B, N'Tsiba F, Barrière G (1985) Enzymatic variability of beech stands (Fagus sylvatica $\mathrm{L}$ ) on three scales in Europe: evolutionary mechanisms. In: Genetic Differentiation and Dispersal in Plants (Jacquart $P$, Heim G, Antonovics J, eds) NATO ASI Series, Montpellier, 17-39

Cuguen J, Merzeau D, Thiebaut B (1988) Genetic structure of the European beech stands (Fagus sylvatica L): F-statistics and importance of the mating system characteristics in their evolution. Heredity 60, 91-100

Felber F, Thiebaut B (1982) La hêtraie méridionale française : structure génétique en relation avec les conditions écologiques : In: Struktur and Dynamik von Wäldern, Ber der 25 intern Symposien der intern Vereinig für Vegetationskunde Rinteln 1981. AR Gartner Verlag, Vaduz, Liechtenstein, 459-473

Felber F, Thiebaut B (1984) Étude préliminaire sur le polymorphisme enzymatique du hêtre (Fagus sylvatica L) variabilité génétique de deux systèmes de peroxydases en relation avec les conditions écologiques. Oecol Plant $5,133-150$

Gregorius HR (1975a) A model for genetic relationship among offspring from openpollinated plant populations. Theor App/ Genet $46,109-115$

Gregorius HR (1975b) A model of the determination of the variance in genetic relationship among offspring from open-pollinated plant populations. Theor App/ Genet 46, 157-163

Gregorius HR, Krauhaussen J, Müller-Starck G (1986) Spatial and temporal differentiation among the seeds in a stand of Fagus sylvatica L. Heredity 56, 255-262 
Hamrick JL, Linhart YB, Mitton JB (1979) Relationships between life-history characteristics and electrophoretically detectable genetic variation in plants. Ann Rev Ecol Syst 10, 173-200

Jalut M, Sacchi D, Vernet JL (1975) Mise en évidence d'un refuge tardiglaciaire à moyenne altitude sur le versant nord-oriental des Pyrénées (Belirs, alt $960 \mathrm{~m}$, Aude). CR Acad Sci Paris, Sér D, 280, 1781-1784

Kim ZS (1979) Inheritance of leucine aminopeptidase and acid phosphatase isoenzymes in beech (Fagus sylvatica L). Silvae Genet 28, 68-71

Kim ZS (1980) Veränderung der genetischen Struktur von Buchen-Populationen durch Viabilitätsselektion im Keimlingsstadium. Forstwiss Diss, Univ Gottingen

Knowles $P$ (1984) Genetic variability among and within closely spaced populations of lodgepole pine. Can J Genet Cytol 26, 177-184

Knowles P, Grant MC (1985) Genetic variation of Lodgepole pine over time and microgeographical space. Can J Bot 63, 722-727

Koehn RK (1978) Physiology and Biochemistry of Enzyme Variation: the Interface of Ecology and Populations Genetics (PF Brussard, ed) Springer, New York

Linhart YB, Mitton JB, Sturgeon KB, Davis ML (1981) Genetic variation in space and time in a population of Ponderosa pine. Heredity 46, 407-426

Loveless MD, Hamrick JL (1984) Ecological determinants of genetic structure in plant populations. Ann Rev Ecol Syst 15, 65-95

Lundkvist K, Rudin D (1977) Genetic variation in eleven populations of Picea Abies as determined by isozyme analysis. Hereditas $85,67-$ 74

Malecot G (1969) The Mathematics of Heredity. WH Freeman and Co, San Francisco

Merzeau D, Di Giusto F, Comps B, Thiebaut B, Letouzey J, Cuguen $J$ (1989) The allozyme variants of beech (Fagus sylvatica $L$ ): inheritance and application to a study of the mating system. Silvae Genet 38, 195-201

Miller RG (1974) The jackknife-a review. Biometrika 61, 1-15
Misic $V$ (1957) The Variability and Ecology of the Beech in Yugoslavia. Srpska Akademija Nanka Institut za Ekologiju i Biogeografila

Mitton JB, Linhart YB, Hamrick JB, Beckmann JS (1977) Observation on the genetic structure and mating system of Ponderosa pine in the Colorado front range. Theor Appl Genet 51, 5-13

Mitton JB, Sturgeon KB, Davis ML (1981) Genetic differentiation in Ponderosa pine along a steep elevational transect. Silvae Genet 29 , 100-103

Müller-Starck G (1985) Genetic differences between "tolerant" and "sensitive" beeches ( $\mathrm{Fa}$ gus sylvatica L) in an environmentally stressed adult forest stand. Silvae Genet 34, 241-247

Müller-Starck G (1989) Genetic implications of environmental stress in adult forest stands of Fagus sylvatica L. In: Genetic Effects of Air Pollutants in Forest Tree Populations (Scholz F, Gregorius HR, Rudin D, eds)' Springer, Berlin, 127-142

Nei M (1973) Analysis of gene diversity in subdivided populations. Proc Natl Acad Sci USA 70, 3321-3323

Nei M (1977) F-statistics and analysis of gene diversity in subdivided populations. Ann Hum Genet 41, 225-233

Nielsen PC, Schaffalitzky de Muckadell M (1954) Flower observations and controlled pollinations in Fagus. $Z$ Forstgenet 3, 6-17

N'Tsiba F (1984) Étude de la variabilité génétique du hêtre (Fagus sylvatica $L$ ) : polymorphisme enzymatique des hêtraies dans les Alpes méridionales à des échelles d'observation différentes. Thèse DocteurIngénieur, Université de Nancy I, Nancy, France

Paquereau MM (1965) Les refuges végétaux d'après les analyses polliniques dans le sudouest de la France. Actes Soc Linn Bordeaux, Sér B 102, 1-7

Pons A (1983) La paléoécologie face aux variations spatiales du bioclimat méditerranéen. In: Colloque, Bioclimatologie méditerranéenne. Fond L Emberger et C Sauvage, Montpellier 1983, II(3), 1-9 
Reynolds J, Weir BS, Cockerham CC (1983) Estimation of the coancestry coefficient: basis for a short-term genetic distance. Genetics 105, 767-779

Ruding D, Ericksson G, Ekberg I, Rasmuson M (1974) Studies of allele frequencies and inbreeding in Scots pine populations by the aid of the isozyme technique. Silvae Genet 23, 10-13

Sakai KI, Park GY (1971) Genetic studies in natural populations of forest trees. III. Genetic differentiation within a forest of Cryptomeria japonica. Theor Appl Genet 41, 13-17

Sercelj A (1970) Das refugial Problem der spätglaziale Vegetationsent wicklung im Norfeld des sudost-Alpenraumes. Mitteil Ostalp Pflanzensoziol Arbeitsgem 10, 76-78

Shea KL (1985) Mating system and population structure in Engelmann spruce and subalpine fir. Ph D Thesis, University of Colorado, Boulder, $C O$

Thiebaut $B$ (1984) Variabilité génétique du hêtre commun (Fagus sylvatica L) dans les milieux montagnards et de hautes altitudes en Europe. In: Colloque, Ecologie et Biogéographie des Milieux Montagnards et de Haute Altitude (CNRS et Museum, ed). Gabas, Doc Ecol Pyrénéenne 3-4, 513-521

Thiebaut $B$, Lumaret R, Vernet $P$ (1982) The bud enzymes of beech (Fagus sylvatica $\mathrm{L}$ ).
Genetic distinction and analysis of polymorphism in several French populations. Silvae Genet 31, 51-60

Tigerstedt PMA (1973) Study on isozyme variation in marginal and central populations of $\mathrm{Pi}$ cea abies. Hereditas 75, 47-60

Triat-Laval H (1978) Contribution pollenanalytique à l'histoire tardi- et post-glaciaire de la végétation de la basse vallée du Rhône. Thèse de Doctorat d'Etat, Université d'AixMarseille III

Van Dijk (1987) A method for the estimation of gene flow parameters from a population structure caused by restricted gene flow and genetic drift. Theor Appl Genet 73, 724-736

Vernet JL (1981) L'histoire du hêtre. In: Le Hêtre (Institut National de la Recherche Agronomique, France, ed) Département des recherches Forestières, Paris, 49-58

Weir BS, Cockerham CC (1984) Estimating Fstatistics for the analysis of population structure. Evolution 36, 1358-1370

Wright $S$ (1943) Isolation by distance. Genetics 28, 114-138

Wright $S$ (1946) Isolation by distance under diverse systems of mating. Genetics 31, 39-59

Wright $S$ (1965) The interpretation of population structure by $F$-statistics with special regard to systems of mating. Evolution 19, 395-420 